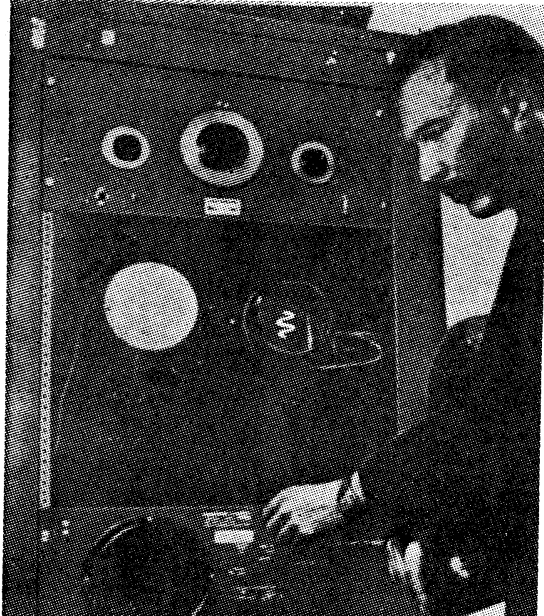

写真 1 (a)明所で使用している透明けい光 面ブラウン管(右) と普通けい光面のブ ラウン管(左)

反応容器および電気炉はパイレックスガラス製で内部 には $1 \sim 2 \mathrm{mmHg}$ の $\mathrm{H}_{2} \mathrm{~S}$ を入れガラス板を $500 \sim 600^{\circ} \mathrm{C}$ に保つ. $\mathrm{Zn}$ 金属と $\mathrm{MnCl}_{2}$ の粉末を少量ずつ加熱容器中 に落下させると蒸発し $\mathrm{H}_{2} \mathrm{~S}$ と反応して生じた $\mathrm{ZnS}: \mathrm{Mn}$ がガラス板上に透明膜として付着する。

膜の厚さはガラス製の容器，電気哣を通して反応中に 反射光の干渉色によって測る，反応に必要な量を一度に 容器内に入れると, 最初に生成された $\mathrm{ZnS}$ が $\mathrm{Zn}$ の蒸 発を防げ，常に一定の割合の $\mathrm{Zn}$ と $\mathrm{MnCl}_{2}$ の混合気体 が得られなくなる。

第 1 表は本方法によって各種の透明けい光面を作る場
合の最適条件および特性である。この 方法によれば $\mathrm{Cl}$ 等の coactivatorを 用いることが容易なために普通の粉末 $\mathrm{ZnS}$ けい光面の場合と同様な活性剂 を用い得る。

膜の厚さは注意深くガラス板を洗滌 しても $0.5 \mu$ 厚程度までは透明である が，これ以上厚くなると表面が曇り始 める. しかし膜は非常に丈夫なために 微粒子の研磨剤 Shamva や Precisio nite 等で表層の暑りを取り除き, 更に 付着を繰返すことによって $5 \mu$ 厚程度 まで透明な層を作ることができる。

\section{2. 真空蒸着加熱法(14)}

真空蒸着装置は普通に用いられるも ので良く蒸着の際の真空度は $5 \times 10^{-\varepsilon}$ 万透明计い光面製作装置 $\mathrm{mmHg}$ 程度が必要で, 被着ガラスの表面は蒸気反応法 の場合と同じく充分清浄に保つ必要がある. 蒸着に使用

第 1 表 代表的な蒸気反地法比こる透明けい光面

\begin{tabular}{|c|c|c|c|c|c|}
\hline & 反 & 成 & 発 & 特 & 性 \\
\hline $\begin{array}{l}\mathrm{Zn} \\
\text { 重量 }\end{array}$ & $\begin{array}{l}\mathrm{ZnCl}_{2} \\
\text { 重 量 }\end{array}$ & 活 性 剂 重 量 & $\begin{array}{l}\text { 得られたけ } \\
\text { い光体組成 }\end{array}$ & $\mathrm{CR}$ & $\begin{array}{l}3650 \\
\text { UV }\end{array}$ \\
\hline $\begin{array}{r}\% \\
100\end{array}$ & $\%$ & $\%$ & $\mathrm{ZnS}$ & $\times$ & $x$ \\
\hline 70 & 30 & ベースに予めMnフイル & $Z n S: Z n$ & 青 & $x$ \\
\hline $\begin{array}{r}100 \\
69\end{array}$ & 29 & $\begin{array}{l}\text { 公付着 } \\
2.0\left(\mathrm{MnCl}_{2}\right)\end{array}$ & $\begin{array}{l}\text { ZnS:Mn } \\
\mathrm{ZnS}: \mathrm{Mn}, \mathrm{Cl}\end{array}$ & $\begin{array}{c}\text { 黄 } \\
\text { 黄十青 }\end{array}$ & $\begin{array}{l}\times \\
\text { 黄 }\end{array}$ \\
\hline 70 & 30 & $0.1\left(\mathrm{Cu}_{2} \mathrm{Cl}_{2}\right)$ & $\mathrm{ZnS}: \mathrm{Cu}$ & 緑 & 緑 \\
\hline 68 & 28 & $4.0\left(\mathrm{AsI}_{3}\right)$ & $\mathrm{ZnS}: \mathrm{As}$ & 黄＋青 & 黄 \\
\hline 63 & 31.5 & $5.5(P)$ & $Z_{\mathrm{nS}}: \mathrm{P}$ & 緑一青 & 緑 \\
\hline 64 & 32 & $2.7\left(\mathrm{AsI}_{3}\right)+1.3(\mathrm{P})$ & ZnS:As, $\mathrm{P}$ & 白 & 緑黄 \\
\hline
\end{tabular}

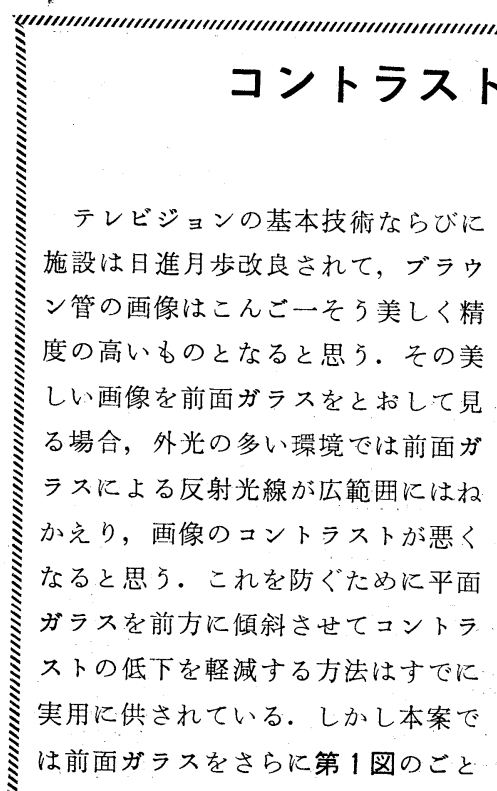

生産にも受像機は特別の設計变更 をせずとも受像機母体は従来通り で，エスカッションだけ特別部品と して製作し，使用場所により適宜前 枠とガラスだけ交換して母体に取り

傾斜と同一角度傾斜した場合，反射 光線は平面より一そう小範囲に集 り，かつ下方に落すことができるの で無反射の範囲の視界が多くなる. 写真のような試作品で害験した結 果, 17 インチ用に半径 $132 \mathrm{~cm}$ の 曲面を使用して見たがこの程度では ヒズミ, 屈折, 透過率等の点で視覚 に悪い結果はない。価格子現在とほ ぼ同一で, 左右からの視界も広く， また磨ガラス, 強化ガラスでも簡単 に製作でき，着色も可能である.

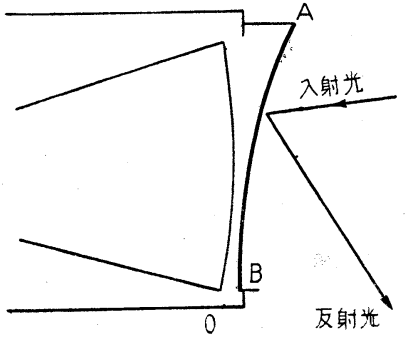

A.B が前面ガラス

第 1 図 
するけい光体は粉末けい光体として最も発光能率の高い ものを使用し，蒸着に際しては粉末けい光体と同じ組成 を得るために完全に蒸発させる.

この方法で得られる代表的な透明けい光面の例を第 2 表に示す. 表からわかるように現在の段階では活性体を 加えないものか, あるいは Mnを活性体としたものが多 く, $\mathrm{ZnS}: \mathrm{Ag}, \mathrm{ZnS}: \mathrm{Cu}$ 等のように coactivator を要する ものは, 熱処理の際にそれを導入する必要がある(16).

このようにして得られたけい光面はけい光体の基体と 活性体とが無晶形の異なった相として存在しているらし く，発光はほとんどの場合起らない。これを熱処理する 々無晶形の基体化合物は crystallite 化すると同時に, 活性体が基体中に拡散する.この加熱処理の温度は高い ほど能率の良いけい光面が得られるが, 過熱によっては ガラスの軟化, 結晶の過大な成長と真空加熱の際には再 蒸発が起るので適当な処理温度が定まる.

\section{透明けい光面の光学的電気的特性}

\section{1. 輝点のボケ}

集束した電子ビームがけい光面を刺㦸した場合に生ず る輝点は, 光の散乱の効果がガラス

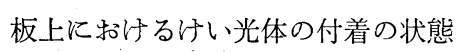
によって第 2 図のようになる。すな わち( $\mathrm{a}$ )光学的接触の非常に少い粉 末けい光体による通常のけい光面, (b) 完全に光学接触した透明かつ平 滑なけい光体層, (c) 完全に光学接 触し透明であるが, 表面のみが散乱

つけて使用するょうにすればよい。 しかし用途により曲りと傾斜の度合 （中心点の決定）によりいろいろの 現象が出るのでな怙若干工夫しなく てはならない点がある.こんご放送 局が增加し, 受像機が普及するに従 ってわが国の生活椂式, 家屋構造の 内で一層多くの人が様々の見方をす る場合が多くなるであるう、特に集 会所, 業務所等で集団視聴する場合 は外光環境によって起る画質の低下 を改善することが望ましい。

例光ば教育テレビ放送をわが国の 学校教室で利用する場合, 衛生的で 開放的な明るい環境でしかも多数の 生徒に同時に聴視させることが望ま
性のけい光体層, この 3 種について輝点のパターンはそ れぞれ(a)ではけい光体粒子間の散乱とガラス前面の反 射により中心は明るいが低輝度の大さい円板状となる。 (b)では入射ビームと同径の輝点となり，(c)ではガラ スの前面より反射しそ光はある角度で最大となり，それ がけい光体外側の面で散乱されるために, 内側のエッジ が鋭く，外側では徐々に減衰したリング状のものが入射 ビームとほぼ同径の輝点の周りに同心につけ加わる. し たがって透明平滑けい光面では, 解像度が極めて優れて いることがわかる.

\section{2. けい光面内の反射}

平滑平行な透明けい光面での発光は螢光体またはガラ スの臨界立体角内に放射される光のみが観察者に認めら れ,それ以外の光はけい光面または下地ガラス内を, 全反 射を繰返して吸収され，残部は層の断面より無効に放出 される. $\mathrm{ZnS}$ (屈折率2.3)を例にとって計算すると，簡 単な理論から有効な光量は僅か飞全体の $5 \%$ 程度となる。

したがって, 透明けい光面の発光能率を第 3 図に示す 真空ウルブリヒト球内で測定することが重要となる.こ の装置で, 試料板の周辺断面に吸収体を塗布した場合と,

第 2 表 代表的な蒸着加熱法によるけい光面

\begin{tabular}{|c|c|c|c|c|c|c|}
\hline \multirow{2}{*}{ けい光 体 } & \multirow{2}{*}{ フイラメント } & \multirow{2}{*}{$\begin{array}{l}\text { フィラメ } \\
\text { ント温度 }\end{array}$} & \multirow{2}{*}{ 蒸着時間 } & \multirow{2}{*}{ 下地材料 } & \multicolumn{2}{|c|}{ ：加 熱 処 理 } \\
\hline & & & & & 霑囲気 & 加熱温度 \\
\hline $\mathrm{ZnS}$ & タンタルボート & $50^{\circ} \mathrm{C}$ & 1 時間 & & 真空 $(\mathrm{He})$ & $\underset{5 \sim 15 \text { 分 }}{750 \sim 800^{\circ}} \bar{C}$ \\
\hline $\mathrm{CaF}_{2}: \mathrm{Mn}$ & & $1550^{\circ} \mathrm{C}$ & 5 分 & 石英ガラス & 真 空 & $600 \sim 700^{\circ} \mathrm{C} 5$ \\
\hline $\mathrm{Zn}_{3}\left(\mathrm{PO}_{4}\right)_{2}$ & ニンバ & $1525^{\circ} \mathrm{C}$ & 20 分 & 石 英 & 空気 $\left(\mathrm{O}_{2}\right)$ & $850^{\circ} \mathrm{C} 10$ 分. \\
\hline $\mathrm{CaWO}_{4}$ & & $2000^{\circ} \mathrm{C}$ & 3 分 & ガ ラ ス & 空気 $\left(\mathrm{O}_{2}\right)$ & $550^{\circ} \mathrm{C} 2$ 時間 \\
\hline $\mathrm{Zn}_{2} \mathrm{SiO}_{4}: \mathrm{Mn}$ & タンタルボート & $1300^{\circ} \mathrm{C}$ & 30 分 & 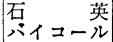 & 空 気 & $1100^{\circ} \mathrm{C} 3$ 時間 \\
\hline
\end{tabular}

しいが,これはテレビの受像環境と しては余り好ましいことではない。 本機は, 前面ガラスによる外光反 射を低減する目的で製作したるので あり，学校に扔ける実験では良好な 結果が得られた。 それは教室に打け る生徒最前列とテ レビとの間には普 通䄪 $2 \mathrm{~m}$ 以上の距 離がある. 本案の ガラス使用の受像 機の場合では外光 による反射光は全 部この $2 \mathrm{~m}$ の間た。 落下するように出

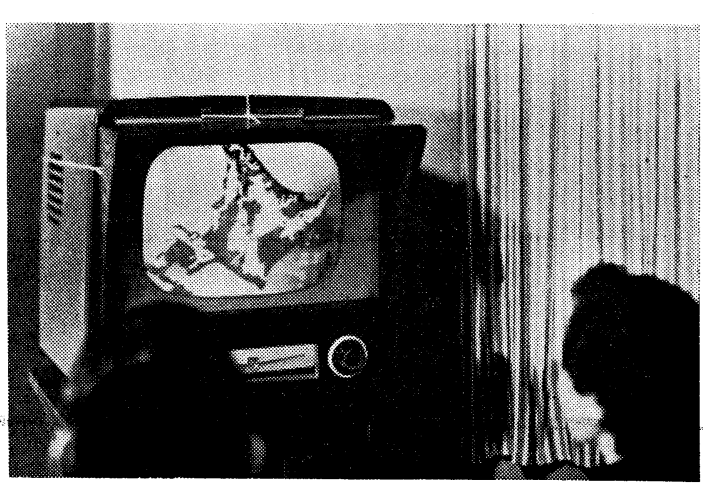

来て, 生徒一人残らず無反射の視界 に入る.ささらにこの受像機全体を少 し前に傾けて設置すれば視角の点か らも更に完全な結果が得られた.

（横浜市神奈川区六角橋町 686)

"IIIIIIIIIIIIIIIIIIIIIIIIIIIIIIIIIIIIIII) 
NEC

\section{T-517 型 テレビ受像機}

\author{
新日本電気株式会社 鈴 木 喜 吉
}

\section{主なる仕様}

受信周波数帯 1 ～12 チャネル かータリー・スイッチ式カスコード・ チューナ.

受信方式 映像中間周波 3 段. イ ンターキャリヤ方式

使用球数 17 球 (CRTを含む)

最大感度 $50 \mu \mathrm{V}$ 以下 $(400 \mathrm{c} / \mathrm{s}, 30$ $\%$ 变調, 出力 $20 \mathrm{~V} \mathrm{p}-\mathrm{p}$ )

総合映像帯域巾 $3.2 \mathrm{Mc}$

中間周波数 映像 $26.75 \mathrm{Mc}$ 音声 $22.25 \mathrm{Mc}$

AGC ピーク值型 AGC (可変抵 抗によるコントロール付き）

$\mathrm{AFC}$ 平衡型のこぎり波 $\mathrm{AFC}$

音声検波 比検波方式

音声出力 $1.2 \mathrm{~W}$

スピーカ $4 \times 6$ インチだ円形, 前 面取付方式

電源 $100 \sim 110 \mathrm{~V}$ (ヒューズ切換 式), $50 \sim 60 \mathrm{c} / \mathrm{s}$, セレンによる半波 犃電圧整流, 完全トランスレス方式 消費電力 $135 \mathrm{~W}$

\section{各部の 説 明}

$$
\begin{aligned}
& \text { チューテ } \\
& \text { ターレット式カスコード・チュー }
\end{aligned}
$$
ナは, 性能的に最もすぐれたものと 思われているが，その接点機構の本 質的な作用より，数カ月ないし1カ 年末満で接点が接点不良となる欠点 を有するため，性能は少し低下する が故障の少いテレビを目標としてロ 一タリースイッチ式のカスコードチ ユーナを採用した. しかしその性能
す種々調査の結果では予想に反し, かえってターレットタイプより優秀 な性能が得られることがわかった。 特にその雑音指数に掠いては第 1 図 に示すようにロータリータイプ的 $4 \mathrm{~dB}$, ターレット・タイプ約 $8 \mathrm{~dB}$ で結 果は $4 \mathrm{~dB}$ 涪ど少い。 またその利得に して为第 2 図に示寸ように決して劣 るものではなく，実際両者を用いた 受像実験に求いても雑音指数の大小 が受像画面の雑音の大小として明確 に観察され SN 比の良い画面が得ら れた。

3CB6 3 段にて十分な利得をとっ ている。また帯域巾を無暗に広く取 ることは，こんご放送局の増加によ る隣接テャネルの妨害, あるいは他 種の妨害が增々多くなるものと想像 されることより，隣接チャネル・ト ラップ等による防除手段はとられて いるが，それにしても広過ぎる帯域 巾は不利である。それゆ帝域巾は $3.2 \mathrm{Mc}$ 程度に留め, 十分のスカ一 ト隇衰特性を得ることとした。その

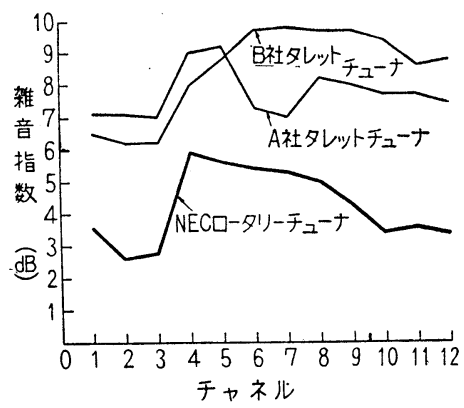

第 1 図各種チューナ雑音指数

\section{映像中間周波増幅}

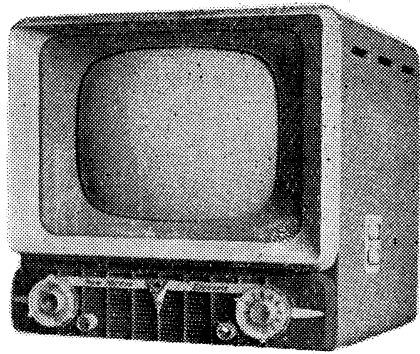

NEC14T-517 型受機像

結果は第3図のような選抧度特性で あり，これで必要十分な水平解像力 は確保し，か觉って妨害の少いすっ きりした映像索得ている。

\section{映像検波, 增幅}

$6 \mathrm{AW} 8-\mathrm{A}$ の 3 極部による映像抒 よび AGC 検波方式はその入力容量 が $5 U 8$ (T) 等よりやや多いので異論 ああるが，実際問題としてその差は $0.5 \mathrm{~dB}$ 程度であり，汷とんど問題に ならないので，あえてラインナップ のすっきりした形象求めて 6 AW8 $\mathrm{A}(\mathrm{T})$ を採用した。映像増巾は $6 \mathrm{~A}$ $\mathrm{W} 8-\mathrm{A}(\mathrm{P})$ であり，4.5 Mc のインタ ーキャリヤもそのプンートから取り 出している.これで最大映像出力は $100 \mathrm{Vp}-\mathrm{p}$ は得られ，普通のコントラ ストでは，この段の混変調による音 声のバズは問題なく，かえってこの 段による $20 \mathrm{~dB}$ の $4.5 \mathrm{Mc}$ の増巾があ り，十分な入力を次段のリミッタに 入れることができる。したがってよ く調整された比検波回路之相まって チューナのチューニング調整の変化 に対してもバズ発生の状態はほとん ど起らない。

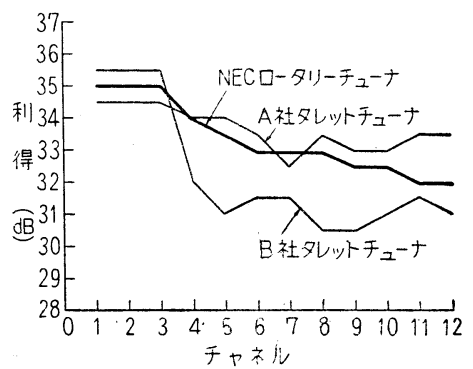

第2図各種チューサ利得 


\section{新型 TV 受像 機}

\section{同期分離回路}

5U8 の五極管部を用いた．普通は 三極管が用いられるが，あえて五極 管を採用したのは，そのシャープカ ット特性により完全に同期信号が分 離できるとともに，その大きな出力 パルスにて次段を十分ドライブし， 完全なクリッパを行わせるためであ るこの結果いかなる入力信号のレベ ルにも無関係に，一定の同期出力が 得られ，安定な同期を保持させるこ とができた。

\section{垂直偏向回路}

6CS7 による変形マルチバイブレ 一タを使用し，ともすると断線の打 それがあるブロッキング発振トラン スの使用を避けた。このプレート出 力よりの帰還回路は特別のフィルタ 回路を用いず，同期信号入力の積分 回路に帰還する方式を用いた。これ は通常の回路に比べ著しく部品の数 が減少してこの部分が甚だ簡単にな り故障の機会も減少し，また割合に 動作が確実で, インターレースも充 分良好である. 6 CS 7 の出力側ユニ ットの動作状態は $E_{B} 360 \mathrm{~V}, I_{p} 15 \mathrm{~mA}$ で振巾, 直線性共に充分な子のが得 られている. 写真 1 にこの格子じま 信号の受像画面を示す.

\section{水平 $\mathrm{AFC}$}

対称型ののこぎり波 $\mathrm{AFC}$ を使用 した。 パルスウ $\mathrm{AFC}$ に比べ球数は 一球增加するが，積分回路が甚だ簡 単なため部品点数が減少し, 球数の 增加を補っている。 また性能的に見 ても巾の広い妨害パルスの浸入した 時の応動性，女るいは長期飞亘って

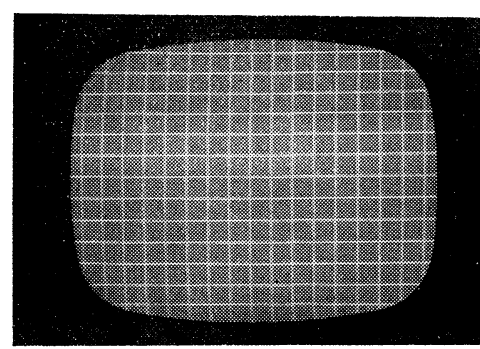

写真1 格子じま信号受像画面
の安定性等からこの方に歩があるも のと考えられる．ただしのこぎり波 AFCで注意せねばならぬことは, そ の無信号時に水平出力管より発生乙 た高圧パルスの高調波が自分のチュ 一ナ回路に入り，これがあたか子同 期信号のような形となって AFC 位 相弁別管に現われる，弁別管に入る このパルスは同じ FBTょり取り出 された比較波形に対して，ある程度 位相の遅れたるのとなり，その結果 弁別管出力として正の電圧が発生す る. 無信号時には零であるべき弁別 管出力に, このような正電圧が発生 するとその水平発振周波数は正常の 位置より低い方に移動する。これが 余りに低くなれば安定コイルとの調 和が破れ，安定コイルの同調周波数 の $1 / 2$ に相当する周波数と, 通常の 周波数を間歇的に繰り返す異状発振 状態となり，FBTより高調の振動 音を発生すると同時に, 異様のラス タを現出する。これに通常の受信状 態で信号が入れば，その本来の発振 周波数に引戻されて実際の受像には 問題はないが，チャネル切り替えの 際とか，無信号時にスイッチインす ると発生する危険があり，これが起 れば利用者に大きな不安感を抱かせ るから，極力防が叔ばならない。こ れは，要するに高圧パルスがチュー ナ回路に誘導しないように十分注意 することで本機に扣いては高調波放 射の多い水平出力管を高圧ヶースの 内部に収容し, その他の FBT 部品 の配置配線には細い注意を払って， このトラブルを完全に防いでいる.

\section{水平偏向回路}

水平出力管 $12 \mathrm{G}-\mathrm{B} 3$ の動作状態は $E_{g_{2}} 105 \mathrm{~V} ， I_{K} 110 \mathrm{~mA} ， E_{B}$ ブースト $450 \mathrm{~V}$ 高圧 $12.5 \mathrm{k}$ ボルトで，もちろ 几充分余裕のある水平振幅が得られ ている．寿命的には高圧出力をるっ と下げたいところであるが，何んと 言っても受像画面の明るさ，ホーカ

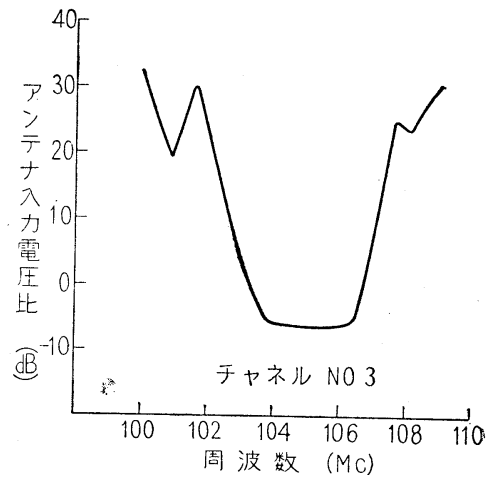

第 3 図 総合選択度特性 スの良否が受像画質を決定付ける最 たる要因であるるので，高圧を低下さ せることはできないので，十分な高 圧を取ってある。水平直線性調節コ イルは用いてないが，このために特 に FBT の使用に留意した。そのた め写真1 の格子じま信号の受像画面 に見られるょうに十分満足できる水 平直線性を得ている.

\section{電源回路}

$600 \mathrm{~mA}$ 直列七一タ管を用いた完 全トランスレス・セットは，初めヒ 一タ事故を懸念してヒータ・チェッ クポイント等が付加されていたが, ここ 1 年余りの経験では $600 \mathrm{~mA}$ 管 のヒータ事故は皆無に近く, ヒ一タ・ チェックポイントも無用の長物と化 して終った感じである。なお B電压 整流にセレンを用いることはどうし でも無理のかかりやすい整流管に比 ベて長寿命を保証している。な扣最 近の真空管部品の進歩は倍電圧整流 で得られる $220 \mathrm{~V}$ 程度の B電圧で何 等不足を感じないものになっている トランスの波れ磁束によるラスタ摇 れの自由, 重量の軽減, 消費電力, 発熱量の低下，それよりもたらされ る各部品の長寿命等, $600 \mathrm{~mA}$ 管使 用の完全トランスレス電源方式は価 格の低下ょり以上に，多くの利点を 所有するるのであり，本 517 型受像 機に拈いてもこれらの長所はいかん， なく取り入れている. 


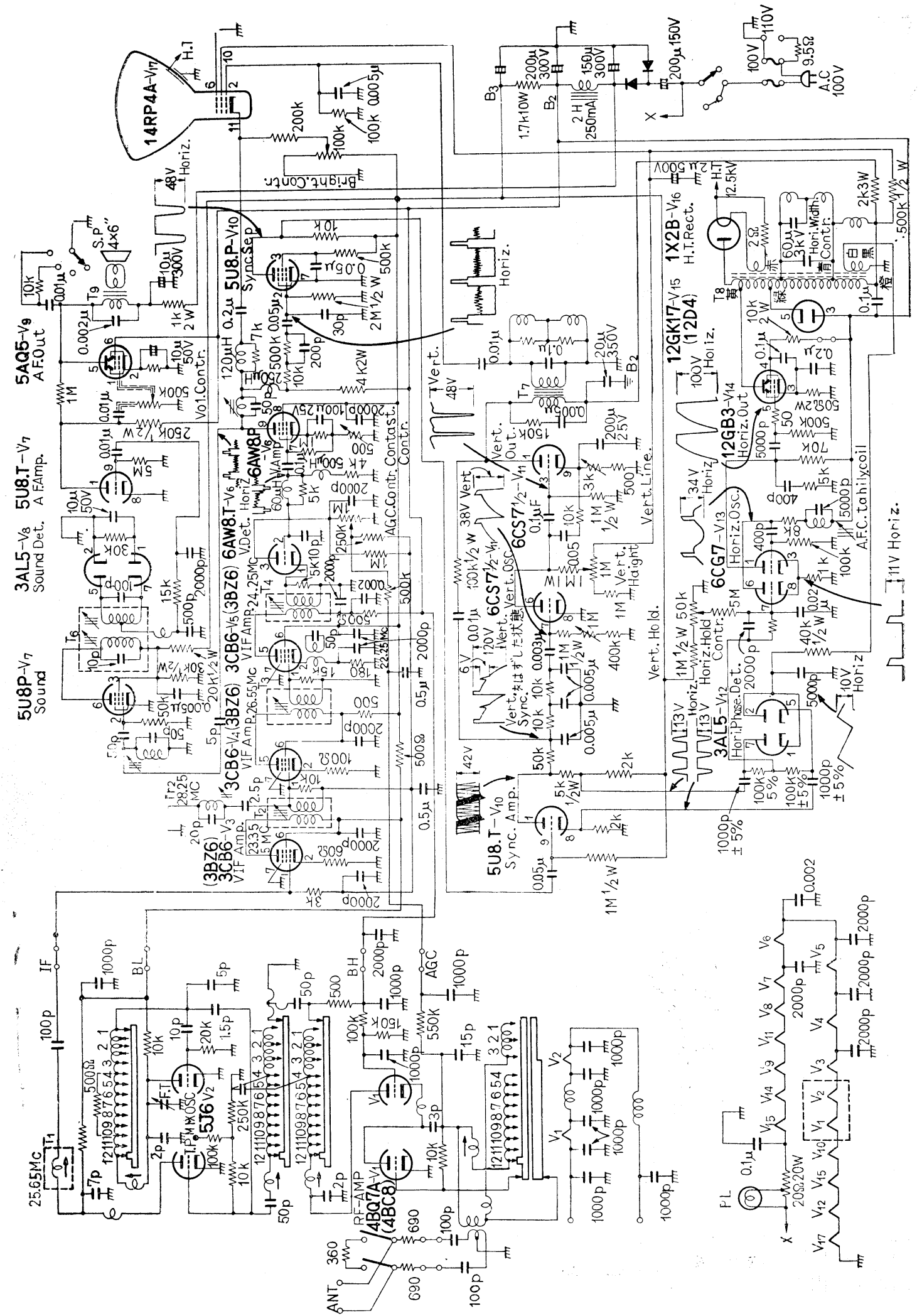

